\title{
Evaluation of the antioxidant activity, antimicrobial effect and acute toxicity of leaves from Allophylus edulis (A. St.-Hil., A. Juss. Cambess \&.) Hieron. ex Niederl
}

\author{
Cleide Adriane Signor Tirloni ${ }^{1}$, Luis Fernando Benites Macorini ${ }^{1}$, Uilson Pereira dos Santos ${ }^{1}$, \\ Paola dos Santos da Rocha ${ }^{2}$, Salete Verônica Barros ${ }^{2}$, Adriana Mary Mestriner Felipe de \\ Melo $^{3}$, Maria do Carmo Vieira ${ }^{4}$, Kely de Picoli Souza ${ }^{1,2}$ and Edson Lucas dos Santos ${ }^{1,2 *}$ \\ ${ }^{1}$ Faculdade de Ciências da Saúde - FCS, Universidade Federal da Grande Dourados, CEP 79804-970, Dourados, Mato \\ Grosso do Sul, Brasil. \\ ${ }^{2}$ Faculdade de Ciências Biológicas e Ambientais - FCBA, Universidade Federal da Grande Dourados, CEP 79804-970, \\ Dourados, Mato Grosso do Sul, Brasil. \\ ${ }^{3}$ Faculdade de Ciências Biológicas e da Saúde, Centro Universitário da Grande Dourados, Jardim Universitário, CEP \\ 79824-900, Dourados, Mato Grosso do Sul, Brasil. \\ ${ }^{4}$ Faculdade de Ciencias Agrarias - FCA, Universidade Federal da Grande Dourados, CEP 79804-970, Dourados, Mato \\ Grosso do Sul, Brasil.
}

Received 9 January, 2015; Accepted 16 March, 2015

\begin{abstract}
Allophylus edulis is a Brazilian plant commonly used in the mid-west region of Brazil for treatment of disorders related to oxidative stress such as diabetes, inflammation, hypertension and digestive diseases. The aims of the present study were to quantify flavonoids and phenolic compounds, evaluate the antioxidant activity, antimicrobial effect and acute toxicity of leaves of $A$. edulis. Ethanolic (EEAE) and aqueous (AEAE) extracts of $A$. edulis were prepared. The antioxidant activity was determined by 2.2-diphenyl-2-picrylhydrazyl (DPPH) free radical scavenging, lipid peroxidation and oxidative hemolysis induced by 2.2'-azobis (2-amidinopropane). The antimicrobial assays of diffusion on solid media and broth microdilution were performed against Staphylococcus aureus, Escherichia coli and Candida albicans. The acute toxicity was assessed in Wistar rats treated with doses of 2 and $5 \mathrm{~g} / \mathrm{kg}$ of body weight. The EEAE presented higher concentrations of flavonoids and phenolic compounds, and higher activity of scavenge DPPH free radicals. In addition, it was more effective against $S$. aureus compared to AEAE. The extracts were unsuccessful against $E$. coli and $C$. albicans. The EEAE prevented the lipid peroxidation in human erythrocytes and inhibited oxidative hemolysis in all the concentrations assessed. During the evaluation of acute toxicity, the dose of $5 \mathrm{~g} / \mathrm{kg}$ of body weight increased hepatic mass. Together, these results demonstrated that the EEAE of leaves of $A$. edulis is more effective than the AEAE, showing antioxidant activity and antimicrobial effect against $S$. aureus, as well as low toxicity.
\end{abstract}

Key words: Cocum, native Brazilian plant, lipid peroxidation, DPPH, AAPH, thiobarbituric acid reactive substances (TBARS), malondialdehyde, Sapindaceae. 


\section{INTRODUCTION}

Medicinal plants have been used for centuries to treat numerous diseases around the world (Garg et al., 2012). The biological activity of extracts from medicinal plants is associated with the presence of phytochemical components, many of which have been studied to develop new drugs (Calixto, 2005). The ethnopharmacological approach is an important method of investigating the properties of medicinal plants. Indeed, it is reported that almost $80 \%$ of the compounds isolated from medicinal plants by the pharmaceutical industry were obtained from information from folk medicine (McClatchey et al., 2009).

There is a growing interest in substances derived from medicinal plants with antioxidant capacity, such as tannins, flavonoids and other phenolic compounds that can eliminate free radicals (Burda and Oleszek, 2001; Casagrande et al., 2014). Free radicals are highly reactive substances that can induce the oxidation of molecules, leading to cellular and tissue damage. The presence of these substances increases the risk of developing several diseases (as diabetes, cancer, inflammatory and cardiovascular diseases) and promotes the premature aging process (Burton and Jauniaux, 2011). Antioxidant compounds can protect the organism through different mechanisms, such as reducing the lipid peroxidation of cell membranes and the damage to proteins and DNA (Farber, 1994; Halliwell, 1992).

Although antioxidant activity has been extensively studied (Raposo et al., 2014), the scientific community's interest in medicinal plants has also increased due to their antimicrobial properties. Indeed, it is known that various components of plants are potential antimicrobial agents (Cowan, 1999). However, in order to ensure the safety of the medicinal use of any plant species, its toxicity should first be investigated. Allophylus edulis is a native Brazilian plant that is popularly known as "chal chal","cocum", "vacum" and "fruto do pombo" it also occurs in the Uruguay, Bolivia, Argentina and the Guayanas (Díaz et al., 2014). Its leaves are used for their antihypertensive, digestive, anti-inflammatory and healing purposes, particularly in the Midwest region of Brazil (Abreu et al., 2005; Alves et al., 2008). Although this plant has been frequently used by the population, there are no existing reports on their biological properties. Therefore, the aim of the present study was to evaluate the antioxidant and antimicrobial properties, as well as the toxicological risk, of the extract of leaves of $A$. edulis.

\section{MATERIALS AND METHODS}

\section{Reagents}

Folin-Ciocalteau and ethanol PA (Chemical Dynamic $®)$; sodium carbonate, butyric alcohol, gallic acid, aluminum chloride, trichloroacetic acid (Vetec $囚) ; ~ q u e r c e t i n$ (Sigma-Aldrich $®)$; malondialdehyde and thiobarbituric acid (Merck®); 2,2'-azobis (2amidinopropane) (AAPH) and and 2,2-diphenil-1-picrylhydrazil $\left(\mathrm{DPPH}^{\circ}\right)$ (Sigma-Aldrich $\AA$ ); ascorbic acid (Proquímios $\left.{ }^{\circledR}\right)$ and butyl hydroxy toluene $(\mathrm{BHT})$ (Via farma $\left.{ }^{\circledR}\right)$; Mueller Hinton agar and Mueller Hinton broth (Merck Brasil囚).

\section{Plant material and preparation of extracts}

The leaves of $A$. edulis were collected in April, 2011, in native Cerrado located at $424 \mathrm{~m}$ altitude, latitude $22^{\circ} 05^{\prime}{ }^{\prime} 545^{\prime \prime}$ and longitude $055^{\circ} 20^{\prime} 746^{\prime \prime}$, in the countryside of Dourados, Mato Grosso do Sul/Brazil. The species was identified by botanist and deposited in the Herbarium of the Federal University of Grande Dourados (UFGD). The species has been cataloged in the voucher specimen number 4676 . After drying in air-circulation oven $\left(40^{\circ} \mathrm{C}\right)$ for seven days, the leaves were pulverized in a Wiley mill. For each gram of powder $10 \mathrm{ml}$ of $80 \%$ ethanol or distilled water in the ratio of $1: 10$ was added. The ethanolic extract from $A$. edulis was kept on maceration, under constant stirring and at room temperature, for four weeks; the aqueous extract of $A$. edulis kept macerating under constant stirring at $4^{\circ} \mathrm{C}$ for one week. After that, the extracts were filtered through filter paper, rotaevaporated and lyophilized. The yield of extracts (in percentage) was calculated by the expression: $R(\%)$ : (dry extract mass/dry plant material mass) $\times 100$. The dried extracts were kept in a freezer $\left(-20^{\circ} \mathrm{C}\right)$ for subsequent studies. The dry extract obtained from the ethanol solvent was named EEAE and the one obtained from water was called AEAE.

\section{Determination of total polyphenols}

The content of total polyphenols was determined by FolinCiocalteau method described by Meda et al. (2005). An aliquot of $0.5 \mathrm{ml}(200 \mu \mathrm{g} / \mathrm{ml}$ of EEAE and AEAE) was mixed with $2.5 \mathrm{ml}$ of Folin-Ciocalteau reagent prepared in water (1:10). After $5 \mathrm{~min}$ incubation, $2 \mathrm{ml}$ of aqueous solution of sodium carbonate (14\%) was added to the solution. After $2 \mathrm{~h}$ at room temperature, the reading on spectrophotometer ( $T 70$ UV/VIS spectrometer $P G$ Instruments $\circledR$ ) was performed at a wavelength of $760 \mathrm{~nm}$. The quantification was performed using a calibration curve with gallic acid standard $(0.4$ to $11 \mu \mathrm{g} / \mathrm{ml})$. Ethanol was used as a blank. The analytical curve was plotted using GraphPad Prism 3.0 software being implemented as the linear regression and the equation of the straight line was obtained $(y=a+b . x)$ by correlating the concentration of gallic acid and the absorbance of each sample. The results were expressed in $\mathrm{mg}$ of gallic acid equivalents (GAE) per $100 \mathrm{mg}$ of extract. The assay was performed in triplicate. 


\section{Determination of total flavonoids}

To determine the levels of total flavonoids, the methodology was kept by using the aluminum chloride described by Liberio et al. (2011), with some modifications. An aliquot of $0.5 \mathrm{ml}(200 \mu \mathrm{g} / \mathrm{ml}$ of EEAE and AEAE) solubilized was added to $4.5 \mathrm{ml}$ of a solution of hexahydrated aluminum chloride solution (2\%). After 30 min rest at room temperature, the absorbances were read on spectrophotometer ( $T 70$ UV/VIS spectrometer PG Instruments $®$ ) at a wavelength of $415 \mathrm{~nm}$. To determine the concentration of flavonoids, a calibration curve was prepared using quercetin as standard $(0.4$ to $11 \mu \mathrm{g} / \mathrm{ml})$. Methanol was used as a blank. The analytical curve was plotted using GraphPad Prism 3.0 software being implemented as the linear regression and the equation of the straight line was obtained $(y=a+b x)$ by correlating the concentration of quercetin and the absorbance of each sample. The results were expressed in $\mathrm{mg}$ of quercetin equivalents (QE) per 100 $\mathrm{mg}$ of extract. The assay was performed in triplicate.

\section{Determination of the presence of saponins}

For this test, $10 \mathrm{mg}$ of each extract (EEAE and $A E A E$ ) was solubilized in $2 \mathrm{ml}$ of $80 \%$ ethanol, and then $5 \mathrm{ml}$ of boiling water was added to the mixture. After cooling, it was vigorously stirred, and was followed by a rest period of $20 \mathrm{~min}$. The presence or absence of foam was visually observed. The presence of foam indicates the presence of saponins in the extracts (Barbosa et al., 2004).

\section{Antioxidant assays}

\section{DPPH free radical scavenging activity}

The method of scavenging of free radical 2,2-diphenyl-1picrylhydrazyl (DPPH) was used to determine the antioxidant activity, as described by Gupta and Gupta (2011), with some modifications. A volume of $0.2 \mathrm{ml}$ of the extracts (EEAE and AEAE), solubilized in $80 \%$ ethanol at different concentrations (0.1 to 1000 $\mathrm{g} / \mathrm{ml})$, was homogenized in $1.8 \mathrm{ml}$ of a DPPH $(0.11 \mathrm{mM})$ solution. After $30 \mathrm{~min}$, at room temperature and protected from light, the reading on spectrophotometer at wavelength of $517 \mathrm{~nm}$ was performed. Antioxidants, ascorbic acid and butylated hydroxytoluene $(\mathrm{BHT})$, were used as standard in the same concentrations of the extracts. $80 \%$ ethanol was used as a blank. To determine the percentage of antioxidant activity, the following equation was used:

Inhibition of DPPH free radical $(\%)=(1-$ Absorbance sample/Absorbance control) $\times 100$

For the absorbance control DPPH $(0.1 \mathrm{mM})$ was used. Three independent experiments were performed in duplicate. The $\mathrm{IC}_{50}$, concentration capable of reducing by $50 \%$ the initial concentration of DPPH, was calculated by nonlinear regression after determining the antioxidant activity curve.

\section{Inhibition of lipid peroxidation assay}

After approval by the Ethics Committee of the University Center of Grande Dourados (Unigran), Brazil (CEP No. 123/12), $5 \mathrm{ml}$ of blood from nonsmoking healthy adults was collected, and lipid peroxidation was determined by measurement of malondialdehyde (MDA) formed as described in Campos et al. (2014). Erythrocytes induced to lipid peroxidation by AAPH were used to assess the protective effects of EEAE and of ascorbic acid. The erythrocytes were washed three times with saline $(0.9 \% \mathrm{NaCl})$. A suspension of these erythrocytes was prepared (5\% final hematocrit) and an aliquot of $0.25 \mathrm{ml}$ was homogenized with $0.25 \mathrm{ml}$ extract (EEAE) and ascorbic acid at different concentrations (100 to $175 \mu \mathrm{g} / \mathrm{ml})$. After $30 \mathrm{~min}$ in water bath at $37^{\circ} \mathrm{C}, 0.5 \mathrm{ml}$ of $\mathrm{AAPH}$ solution $(50$ $\mathrm{mM}$ ) was added. After $3 \mathrm{~h}$ in water bath at $37^{\circ} \mathrm{C}$ with constant stirring, an aliquot of $0.5 \mathrm{ml}$ of supernatant was added to $0.5 \mathrm{ml}$ of trichloroacetic acid (20\%). Then, $0.5 \mathrm{ml}$ of the solution was added to $1 \mathrm{ml}$ of thiobarbituric acid (TBA) $(10 \mathrm{nM})$ solution. The homogenate was kept in a water bath at $94^{\circ} \mathrm{C}$ for $45 \mathrm{~min}$. After 45 min the samples were kept at room temperature for 15 min for cooling, followed by addition of $4 \mathrm{ml}$ of butane with subsequent stirring and centrifugation. The reading of the supernatant absorbance was performed on spectrophotometer (532 nm). Lipid peroxidation was determined by quantification of MDA. The calculation for the amount of MDA in the sample was obtained by the formula:

MDA $=$ Absorbance of samples $\times(20 \times 220.32 /$ Absorbance $1,1,3,3-$ tetrahydroxipropane standard)

The results were expressed in $\mathrm{nmol} / \mathrm{ml}$. The experiment was accomplished in duplicate.

Inhibition oxidative hemolysis induced by 2,2- diphenyl-2picryl hydrazyl assay

For this, the method for inducing hemolysis by 2,2- diphenyl-2-picryl hydrazyl (AAPH), described by Valente et al. (2011), with some modifications was used. We used an erythrocyte suspension with a final hematocrit of $2.5 \%$. Erythrocytes were preincubated at $37^{\circ} \mathrm{C}$ for $30 \mathrm{~min}$ in the presence of different concentrations of EEAE and ascorbic acid (100 to $175 \mu \mathrm{g} / \mathrm{ml}$ ). After this period, $0.5 \mathrm{ml}$ of AAPH solution $(50 \mathrm{mM})$ was added. The mixture was incubated for 240 min in a water bath at $37^{\circ} \mathrm{C}$, with periodic stirring. The hemolysis was determined spectrophotometrically at $540 \mathrm{~nm}$, and aliquots for the determination of hemolysis were taken every $60 \mathrm{~min}$ of incubation, diluted in saline and centrifuged at $3600 \mathrm{rpm}$ for $10 \mathrm{~min}$. The percentage of hemolysis was determined using the formula: $A / B \times 100$ (A) abs. of the sample and (B) total hemolysis (erythrocytes with distilled water). All experiments included: negative control (erythrocytes in $0.9 \%$ saline), control of extracts and ascorbic acid (erythrocytes in $0.9 \%$ saline solution with $E E A E$ and ascorbic acid in different concentrations in the presence and absence of $\mathrm{AAPH}$ ), solvent control (erythrocytes in $0.9 \%$ saline solution with $1 \%$ ethanol solvent). Two independent experiments were performed in duplicate.

\section{Antimicrobial assay}

For the antimicrobial activity of the extracts (EEAE and AEAE) the diffusion assay method was kept in a solid medium from the hole, and also the broth microdilution method, as described by Mokale et al. (2011) with some modifications and observing the recommendations of the standard M100 S5 of the National Committee for Clinical Laboratory Standards (NCCLS/CLSI) (2005). 
All strains were purchased from the American Type Culture Collection (ATCC). The identification of microorganisms was confirmed by the Laboratory of Mycology, Department of Mycology of the University Center of Grande Dourados, Unigran, Dourados, MS, Brazil. Three microorganisms were used: gram-positive bacterium Staphylococcus aureus (ATCC: 25923), a gram-negative bacterium Escherichia coli (ATCC: 8739) and the fungus Candida albicans (ATCC: 10231). Microbial inocula were prepared in $0.9 \%$ physiological solution and its density was adjusted according to McFarland turbidity standard scale $0.5\left(5 \times 10^{5} \mathrm{CFU} / \mathrm{ml}\right)$. Fungal and bacterial suspensions were homogenized and sown with a sterile swab and on the surface of Petri plates containing the culture medium agar Mueller Hinton (AMH). With the aid of sterile stainless steel tubes, holes of $6 \mathrm{~mm}$ diameter were made in culture medium. The holes were filled with $0.1 \mathrm{ml}$ of the extract $(300 \mathrm{mg} / \mathrm{ml})$. The plates were kept for $1 \mathrm{~h}$ at room temperature for diffusion of the extracts. Then the plates were incubated in an oven maintained at $37^{\circ} \mathrm{C}$ for 24 and $48 \mathrm{~h}$. As positive controls, we used tetracycline for bacteria and ketoconazole for fungus, both at a concentration of 4 $\mathrm{mg} / \mathrm{m}$. The solvent ethanol $80 \%$ was used as a negative control. The experiment was performed in triplicate. Minimum inhibitory concentration (MIC) and minimum
bactericidal concentration $(M B C)$

The extracts were submitted to a broth microdilution assay for determining the minimum inhibitory concentration and minimum bactericidal concentration according to Bussmann et al. (2010), with some modifications and observing the recommendations of standard M100 S5 of the National Committee for Clinical Laboratory Standards (NCCLS/CLSI) (2005). Sterile plastic microplates containing 96 wells with $100 \mu \mathrm{l}$ of the culture medium AMH were used. The initial wells of the microtiter plate received a $100 \mu \mathrm{l}$ aliquot of the extracts $(300 \mathrm{mg} / \mathrm{ml})$. Then, a serial dilution of the extract was preformed, resulting in concentrations achieved from 1.50 to $1.56 \mathrm{mg} / \mathrm{ml}$. At the end, $100 \mu \mathrm{l}$ of the bacterial inoculum in the concentration $5 \times 10^{5} \mathrm{CFU} / \mathrm{ml}(0.5 \mathrm{McF}$ arland scale) was added to all wells except to the sterility control of the medium (HAM only). In each microplate was used a negative control ( $80 \%$ ethanol). The microplates were incubated in greenhouse at $37^{\circ} \mathrm{C}$ for $24 \mathrm{~h}$. After this period of time, the resulting turbidity was evaluated in a microplate reader (TP Reader NM, Thermo Plate $®$ ) at $620 \mathrm{~nm}$. The $\mathrm{CIM}_{100 \%}$ was defined as the lowest concentration of the extract able to inhibit microbial growth. Two independent experiments were performed in triplicate. To determine the MBC, an aliquot of $20 \mu \mathrm{l}$ was removed from the wells of the determined concentration as MIC and, at least, two upper levels to it, and transferred to Petri plates with HAM medium. The plates were incubated for $24 \mathrm{~h}$ at $37^{\circ} \mathrm{C}$. MBC was defined as the lowest concentration that produced negative subculture. This method determined bacteriostatic (lowest concentration that inhibit of bacterial growth) and bactericidal (lowest concentration that kills a bacteria) effects of the antimicrobial agents (Bakker-Woudenberg et al., 2005).

\section{Acute toxicity assay}

\section{Animals}

After approval by the Ethics Committee on the use of animals (CEUA) of Unigran, number 015/12, this study followed international protocols of the guide for animal testing of chemical substances of the Organization for Economic Co-operation and
Development (OECD) number 425 (2008). The animals were obtained from School of Environmental and Biological Sciences of UFGD, and were kept under conditions of controlled temperature and humidity, fed with ration (purine-Labina $®$ ) and water ad libitum.

\section{Experimental model}

Twelve Wistar rats weighing an average of $226.7 \pm 4.6 \mathrm{~g}$ were used. The animals were randomly divided into 4 experimental groups, each of them containing 3 animals. The experimental groups were: $\mathrm{C}=$ control group that received water; $\mathrm{TC}=$ control group that received a solution of Tween $80(20 \%) ; L D=$ experimental group that received $2 \mathrm{~g} / \mathrm{kg}$ and $\mathrm{HD}=$ experimental group that received $5 \mathrm{~g} / \mathrm{kg}$ of EEAE solubilized in Tween $80(20 \%)$. A single dose by gavage was administrated. After the administration, and daily throughout the experimental period, the presence or absence of clinical toxicity signs (piloerection, tremors, excitability, irritability, muscle contraction, salivation, and death) was observed. The variation in body weight and food and water consumption was evaluated three times a week. On the 15th day, after fasting for $12 \mathrm{~h}$, euthanasia was performed. Organs and tissues were macroscopically examined and stored at $-20^{\circ} \mathrm{C}$. Blood samples were obtained for haematological and biochemical analysis (Asare et al., 2011).

\section{Statistical analysis}

Data were expressed as mean \pm standard error of the mean (SEM). Analyses were performed using variance analysis (ANOVA) followed by Tukey's test or Student $t$ test. The level of significance was set at $p<0.05$. GraphPad Prism 3.0 software was used.

\section{RESULTS}

\section{Preparation of the extracts, determination of phenolic compounds, flavonoids and saponins}

The EEAE and AEAE presented a yield of 8.8 and $10.0 \%$, respectively, after extraction with the solvent. The concentrations of phenolic compounds were $17.6 \pm 0.6$ and $9.0 \pm 0.2 \mathrm{mg} \mathrm{GAE} / 100 \mathrm{mg}$, respectively. Conversely, the concentrations of flavonoids were $2.0 \pm 0.3$ and $1.0 \pm$ $0.2 \mathrm{mg} \mathrm{QE} / 100 \mathrm{mg}$, respectively. Saponins were not detected in any of the extracts.

\section{DPPH free radical scavenging activity}

The extracts and controls were assessed at different concentrations $(0.1$ to $1000 \mu \mathrm{g} / \mathrm{ml})$. The $50 \%$ inhibitory concentration $\left(\mathrm{IC}_{50}\right)$ and the maximal activity of $\mathrm{DPPH}$ free radical scavenging are shown in Table 1. These data showing that the EEAE exhibited an antioxidant capacity 4.5 times lower than that of ascorbic acid and 0.6 times higher than that of $B H T$. On the other hand, the AEAE presented an antioxidant capacity 1.4 times lower than 
Table 1. DPPH radical scavenging activity (\%) of ethanolic (EEAE) and aqueous extracts (AEAE) of $A$. edulis at different concentrations $(\mu \mathrm{g} / \mathrm{ml})$ and $\mathrm{IC}_{50}$ values.

\begin{tabular}{|c|c|c|c|c|c|c|c|c|c|}
\hline Treatments & 0.1 & 1 & 5 & 10 & 50 & 100 & 500 & 1000 & $I_{50}$ \\
\hline Ascorbic acid & $1.8 \pm 1.2$ & $10.2 \pm 4.2$ & $48.5 \pm 3.7$ & $94.2 \pm 2.3$ & $95.2 \pm 1.3$ & $97.7 \pm 0.3$ & $96.0 \pm 0.9$ & $96.3 \pm 0.8$ & $3.9 \pm 0.8$ \\
\hline $\mathrm{BHT}$ & $6.0 \pm 3.6$ & $8.2 \pm 2.4$ & $19.3 \pm 4.6$ & $31.7 \pm 7.4$ & $69.3 \pm 9.5$ & $81.0 \pm 5.3$ & $95.2 \pm 0.7$ & $95.0 \pm 0.6$ & $31.5 \pm 1.9$ \\
\hline EEAE & $6.2 \pm 3.0$ & $6.8 \pm 2.3$ & $13.8 \pm 3.2$ & $27.8 \pm 2.3$ & $91.8 \pm 1.9$ & $96.0 \pm 0.8$ & $91.3 \pm 1.8$ & $94.5 \pm 2.5$ & $17.7 \pm 2.6$ \\
\hline AEAE & $2.8 \pm 1.0$ & $6.0 \pm 1.4$ & $10.0 \pm 4.9$ & $13.8 \pm 1.4$ & $47.2 \pm 2.5$ & $78.3 \pm 2.9$ & $91.8 \pm 2.7$ & $89.0 \pm 1.3$ & $45.8 \pm 4.6$ \\
\hline
\end{tabular}

The results were expressed as mean \pm standard error of the mean $(S E M), n=3$, duplicate. $I_{50}$ represents the half-maximal inhibitory concentration and the values obtained were different between all samples.

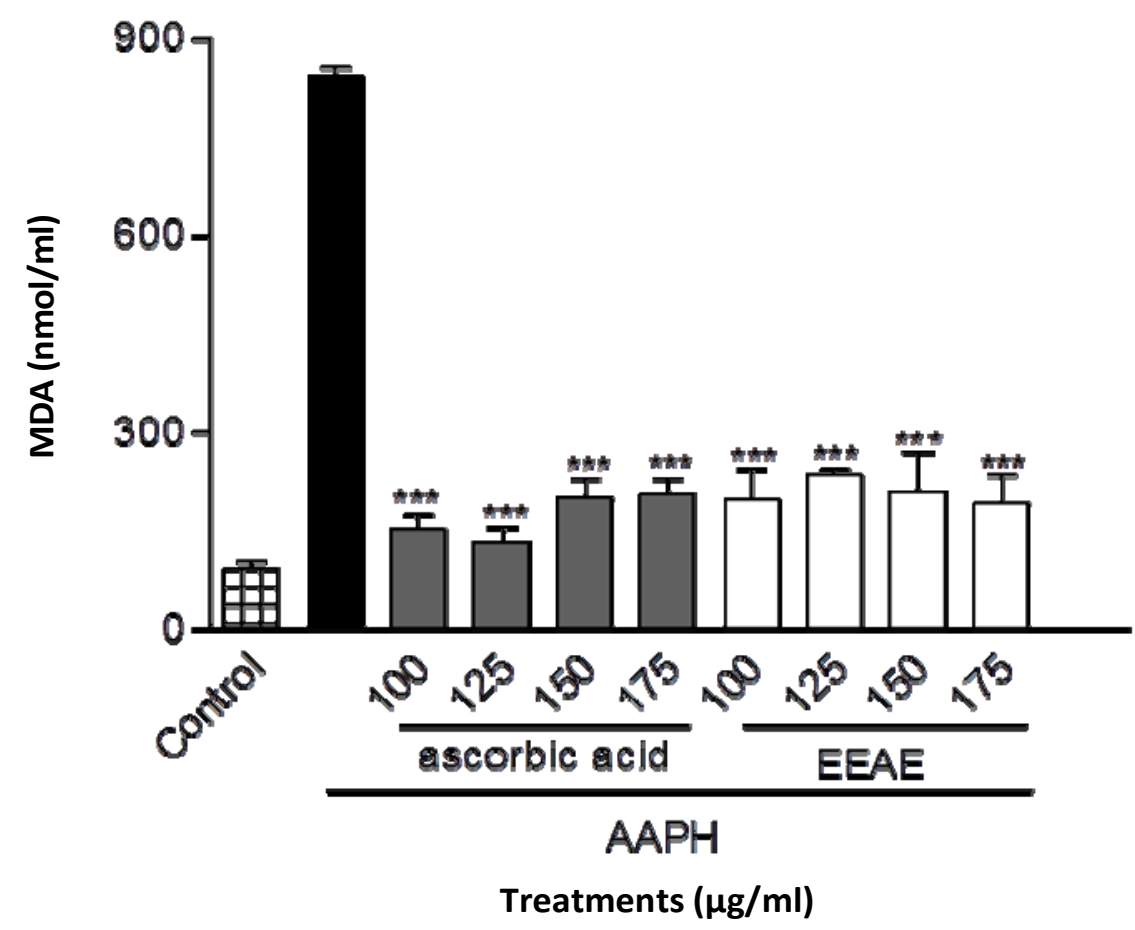

Figure 1. Effects of ethanolic extract of $A$. edulis (EEAE) on the $A A P H$-induced lipid peroxidation of erythrocytes. Control group (erythrocytes incubated with saline solution) and AAPH-treated group (erythrocytes incubated with $50 \mathrm{mM}$ of AAPH). Values are expressed as the mean \pm SEM. ${ }^{*} p<0.001$, compared with AAPH at respective time.

that of ascorbic acid and 11.7 times lower than that BHT. The EEAE exhibited an antioxidant activity 0.4 times higher than that of $\mathrm{AEAE}$, reaching maximal activity at the concentration of $50 \mu \mathrm{g} / \mathrm{mL}$, which is 10 times higher than the AEAE concentration $(500 \mu \mathrm{g} / \mathrm{ml})($ Table 1$)$.

\section{Inhibition of lipid peroxidation}

In this test, the EEAE was able to prevent lipid peroxidation of the erythrocytes induced by the AAPH in all of the concentrations assessed (100 to $175 \mu \mathrm{g} / \mathrm{ml}$ ).
Levels of MDA were between 72 and $77 \%$ lower than those in the group of erythrocytes with AAPH alone. This result was similar to that of ascorbic acid, with levels of MDA between 76 and $84 \%$, which were lower than the control group (Figure 1).

\section{Inhibition of hemolysis induced by AAPH}

All concentrations of the extract tested were able to protect against hemolysis at 60 and $120 \mathrm{~min}$ after the beginning of the test. Despite this, none of the concentra- 

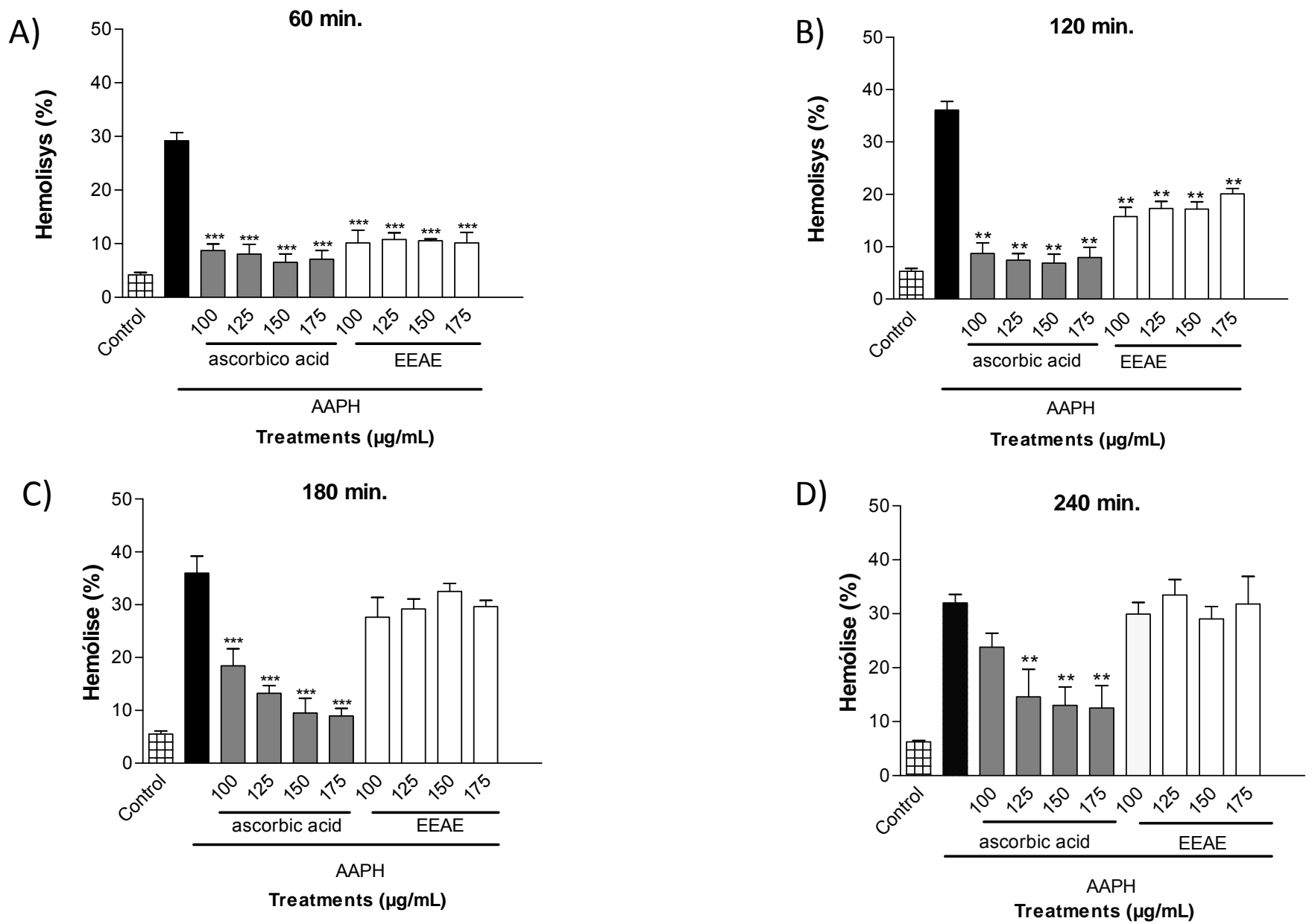

Figure 2. Effects of ethanolic extract of $A$. edulis (EEAE) on the AAPH- induced hemolysis of erythrocytes. Control group (erythrocytes incubated with saline solution) and AAPH-treated group (erythrocytes incubated with $50 \mathrm{mM}$ of AAPH). A) Erythrocytes incubated for $60 \mathrm{~min}$ (B) $120 \mathrm{~min}$, (C) $180 \mathrm{~min}$ and (D) $240 \mathrm{~min}$. The results were expressed as mean \pm standard error of the mean (SEM), $n=2$, duplicate. ${ }^{* *} p<0.01 ;{ }^{* * *} p<0.001$ versus. AAPH at respective time.

tions of the extract were able to protect against hemolysis at 180 and 240 min (Figure 2). The ascorbic acid was able to provide protection at almost all of the concentrations and time-points analyzed, with the exception of the $100 \mu \mathrm{g} / \mathrm{ml}$ concentration at $240 \mathrm{~min}$. None of the concentrations of EEAE, ascorbic acid or solvent significantly affected the rate of basal hemolysis throughout the study period.

\section{Antimicrobial activity and MIC}

The extracts were effective against the bacterium $S$. aureus. The EEAE exhibited an inhibition zone of $20.3 \pm$
$0.3 \mathrm{~mm}$. In addition, bactericidal activity was detected at the concentration of $150 \mathrm{mg} / \mathrm{ml}$. Similarly, the AEAE presented an inhibition zone of $17.3 \pm 1.2 \mathrm{~mm}$, but only bacteriostatic activity at the same concentration of 150 $\mathrm{mg} / \mathrm{ml}$. None of the extracts were effective against $E$. coli and C. albicans (Table 2).

\section{Test of acute toxicity}

In this test, no clinical signs of toxicity, macroscopic changes in the organs or death were observed throughout the study. In addition, no changes in the water/food intake and body weight of the animals were 
Table 2. Diameter of inhibition zones, MIC and MBC/MFC of ethanolic (EEAE) and aqueous (AEAE) extracts of $A$. edulis.

\begin{tabular}{|c|c|c|c|c|c|c|c|c|c|c|c|c|}
\hline \multirow[b]{2}{*}{ Treatments } & & \multicolumn{5}{|c|}{ Staphylococcus aureus } & \multicolumn{3}{|c|}{ Escherichia coli } & \multicolumn{3}{|c|}{ Candida albicans } \\
\hline & & DI & MIC & MBC & Activity & $\begin{array}{c}\text { F. effectiveness } \\
(\%)\end{array}$ & DI & MIC & MBC & DI & MIC & MBC \\
\hline Ketoconazole & - & - & - & - & - & - & - & - & - & $24 \pm 1.2$ & - & - \\
\hline Tetracycline & - & $24.0 \pm 1.0$ & - & - & - & 100 & $30.0 \pm 2.0$ & - & - & - & - & - \\
\hline ulis & EEAE & $20.3 \pm 0.3$ & 150 & 150 & bactericidal & 85 & 0 & - & - & 0 & - & - \\
\hline
\end{tabular}

DI: diameter of inhibition zone. Ketoconazole and tetracycline $(4 \mathrm{mg} / \mathrm{ml})$, F: effectiveness: samples / Tetracycline $\times 100$, EEAE and AEAE (300 $\mathrm{mg} / \mathrm{ml}$ ), MIC and MBC (150 to $1.56 \mathrm{mg} / \mathrm{ml})$. -: not tested. The results were expressed as mean \pm standard error of the mean $(S E M)$, $n=2$, triplicate. ${ }^{*} p<0.05$ versus tetracycline treatment.

Table 3. Body weight, food/water intake, hematological and biochemical indices of the Control group (C) and the Tween control group (TC). Low dose group (LD = $2 \mathrm{~g} / \mathrm{kg}$ $\mathrm{BW}$ ) and High dose group (HD = $5 \mathrm{~g} / \mathrm{kg} \mathrm{BW}$ ) on day 15 after the administration of ethanolic extract (EEAE) of $A$. edulis in Wistar rats.

\begin{tabular}{lcccc}
\hline Variable & C & TC & LD & HD \\
\hline Food intake $(\mathrm{g} / 24 \mathrm{~h})$ & $22.0 \pm 1.0$ & $22.0 \pm 1.0$ & $20.0 \pm 0.6$ & $20.0 \pm 1.7$ \\
Water intak $(\mathrm{ml} / 24 \mathrm{~h})$ & $44.0 \pm 3.1$ & $38.0 \pm 1.4$ & $42.0 \pm 1.3$ & $42.0 \pm 2.2$ \\
B.w $1^{\circ}$ day $(\mathrm{g})$ & $226.7 \pm 4.6$ & $231.4 \pm 7.1$ & $232.0 \pm 7.8$ & $220.2 \pm 7.5$ \\
B.w $15^{\circ}$ day $(\mathrm{g})$ & $246.3 \pm 3.8$ & $250.0 \pm 8.1$ & $251.7 \pm 8.4$ & $233.8 \pm 12.7$ \\
Liver $(\mathrm{g} / 100 \mathrm{~g})$ & $3.2 \pm 0.1$ & $3.0 \pm 0.1$ & $3.30 \pm 0.1$ & $3.6 \pm 0.1^{*}$ \\
Kidney $(\mathrm{g} / 100 \mathrm{~g} \mathrm{BW})$ & $0.66 \pm 0.1$ & $0.69 \pm 0.1$ & $0.66 \pm 0.1$ & $0.70 \pm 0.0$ \\
Heart $(\mathrm{g} / 100 \mathrm{~g} \mathrm{BW})$ & $0.38 \pm 0.1$ & $0.39 \pm 0.0$ & $0.41 \pm 0.1$ & $0.41 \pm 0.0$ \\
Lung $(\mathrm{g} / 100 \mathrm{~g} \mathrm{BW})$ & $0.58 \pm 0.0$ & $0.57 \pm 0.1$ & $0.54 \pm 0.1$ & $0.61 \pm 0.1$ \\
RBC $\left(10^{6} / \mathrm{ml}\right)$ & $8.9 \pm 0.1$ & $8.6 \pm 0.1$ & $8.1 \pm 0.6$ & $8.5 \pm 0.1$ \\
WBC $\left(10^{3} / \mathrm{ml}\right)$ & $7.4 \pm 0.5$ & $5.9 \pm 1.4$ & $6.3 \pm 1.4$ & $6.1 \pm 0.7$ \\
HGB $(\mathrm{g} / \mathrm{dl})$ & $13.8 \pm 0.1$ & $13.5 \pm 0.2$ & $13.5 \pm 0.3$ & $13.8 \pm 0.2$ \\
HCT $(\%)$ & $47.1 \pm 0.4$ & $45.6 \pm 0.4$ & $44.3 \pm 1.7$ & $47.0 \pm 0.3$ \\
PLT $\left(10^{3} / \mathrm{ml}\right)$ & $977.7 \pm 60.2$ & $996.0 \pm 100.3$ & $902.3 \pm 68.2$ & $790.5 \pm 46.5$ \\
URE (mg/dl) & $31.6 \pm 4.5$ & $30.2 \pm 0.9$ & $31.9 \pm 0.4$ & $31.5 \pm 1.1$ \\
CR (mg/dl) & $0.2 \pm 0.03$ & $0.3 \pm 0.06$ & $0.3 \pm 0.03$ & $0.3 \pm 0.03$ \\
Y-GT (U/L) & $0.7 \pm 0.3$ & $0.7 \pm 0.3$ & $0.5 \pm 0.5$ & $0.7 \pm 0.3$ \\
ALT $(\mathrm{U} / \mathrm{L})$ & $57.0 \pm 8.2$ & $60.0 \pm 2.9$ & $56.0 \pm 3.1$ & $57.0 \pm 4.5$ \\
AST (U/L) & $152.7 \pm 1.8$ & $271 \pm 32.9^{*}$ & $183.3 \pm 20.3$ & $198.3 \pm 22.4$ \\
\hline
\end{tabular}

$\mathrm{BW}=$ body weight $\mathrm{WBC}=$ White Blood Cells; RBC = Red Blood Cells; HGB =Hemoglobin; $\mathrm{HCT}=$ Hematocrit; $\mathrm{PLT}=$ Platelet; URE = urea; $\mathrm{CR}=$ creatinine; $\mathrm{Y}-\mathrm{GT}=\mathrm{Y}$ glutamyltranspeptidase; $\mathrm{ALT}=$ alanine aminotransferase; $\mathrm{AST}=$ aspartate aminotransferase. $p<0.05$ versus $C$ group.

detected. At a dose of $2 \mathrm{~g} / \mathrm{kg}$, the extract did not change any of the parameters assessed. However, the dose of 5 $\mathrm{g} / \mathrm{kg}$ caused an increase in the liver weight of treated animals, when compared with the control group. Finally, the control group treated with tween exhibited an increase in serum levels of aspartate aminotransferase, when compared with the control group treated with water
(Table 3).

\section{DISCUSSION}

In recent years, the number of studies on alternative therapies for several diseases has increased, with 
medicinal plants as the main target for scientific research seeking to develop more efficient new drugs and reduce side effects. In Brazil, several species of plants with medicinal properties are used, although less than $5 \%$ of plants have been phytochemically and biologically studied (Calixto, 2005; Simões et al., 2004). Among these plant species, $A$. edulis contains compounds with anti-insect activity (Diaz et al., 2014), flavonoids and phenolic molecules, which are directly associated with their biological activities. Previous studies have demonstrated that essential oils, alkaloids (Bandoni et al., 1972; Yajia et al., 1999) and polyol L-quebrachitol are the main constituents of this vegetal (Diaz et al., 2008). The presence of flavonoids in $A$. edulis extract could be associated with DPPH free radical scavenging and antioxidant activities.

Flavonoids present a chemical structure which favors the inactivation of free radicals, since free hydroxyl groups are able to donate hydrogen and electrons which will neutralize the free radicals (Burda and Oleszek, 2001). Several phenolic and flavonoid compounds with antioxidant activity have been identified and isolated from plant extracts (Lee et al., 1998). These constituents are represented by various molecules which are considered natural antioxidants (Dryden et al., 2006; Middleton, 1998).

The higher antioxidant activity exhibited by EEAE compared to AEAE could be related to higher concentrations in the ethanol extract of phenolic and flavonoid compounds. The antioxidant activity demonstrated by EEAE was 2.7 times higher than that reported in a previous study using fruit of the same species (Umeo et al., 2011). Other antioxidant properties of EEAE have been demonstrated by its ability to prevent the lipid peroxidation of the membranes of human erythrocyte, as evidenced by the reduction of malondialdehyde production, and its ability to prevent oxidative hemolysis.

These activities could be attributed to the phenolic compounds of EEAE, which are able to eliminate the peroxyl radicals produced by the thermal decomposition of AAPH. This reaction may occur before the action on the lipid molecules of the erythrocyte membrane, breaking the chain reaction of free radicals, which inhibits lipid peroxidation and consequently, hemolysis (Silva et al., 2011). Previous studies have reported that phenolic compounds are the main components associated with the anti-hemolytic ability of natural products (Valente et al., 2011; Campos el., 2014; Casagrande et al., 2014).

Besides the presence of phenolic compounds, other metabolites have been described in terms of their protective ability against oxidative hemolysis. For example, polyol L-quebrachitol, previously described for this species (Diaz et al., 2008), could be responsible for the antioxidant activity observed. A previous study demonstrated the antioxidant activity of L-quebrachitol in other plant species belonging to the same family of the $A$. edulis (Nobre Junior et al., 2006). These protective activities are of great importance, since the effects of oxidative stress on the organism include damage to the cell membrane by lipid peroxidation (Halliwell, 1992). This oxidative process is present in various pathologies, such as diabetes, cancer, cardiovascular and inflammatory diseases (Burton and Jauniaux, 2011).

Antimicrobial activity is another significant biological property. Indeed, it is known that there is an increase in the number of new multi-resistant strains to conventional drugs, which cause high morbidity and mortality rates among patients and pose a threat to public health (Kamicker et al., 2008). The antimicrobial activity of EEAE and AEAE was assessed against $S$. aureus, E. coli and $C$. albicans, with effective results associated with the treatment of $S$. aureus. This is an important finding, since $S$. aureus has been reported as a multi-resistant bacterium of medical concern (Russell, 2002). This agent is responsible for several syndromes, such as food poisoning, toxic shock syndrome, skin lesions and atopic dermatitis (Guay, 2003). Among the molecules related to the antimicrobial activity of natural products, flavonoids are one of the most important due to their ability to interfere in the synthesis of nucleic acid and the energetic metabolism of microorganisms. In addition, they can also bind to the proteins of cell membranes, causing their death (Cowan, 1999; Cushnie and Lamb, 2005, 2011). However, the extracts were not able to inhibit the growth of the gram-negative bacterium $E$. coli and the fungus $C$. albicans. Gram-negative bacteria and fungi exhibit a complex cell membrane, which is difficult to penetrate (Braun, 2009). Most likely, the different composition of the cell membrane of these organisms is the cause of the resistance observed herein. The resistance of these microorganisms to plant extracts has already been reported (Engels et al., 2011; Hendra et al., 2011).

Toxicological studies of medicinal plants are important to understand the eventual toxic effects that could reduce its medicinal value. Many studies are performed in Wistar rats to evaluate the toxicity of the leaves extract from medicinal plants. In these animals the most important signs of toxicity are characterized by reduction of body weight, hind limb paralysis, increase in creatinine, aspartate aminotransferase, sodium and potassium serum levels, reduction of urea and albumin, leucopenia and small alteration in color and consistency of viscera (Félix-Silva et al., 2014). Considering the popular use of $A$. edulis as a medicinal plant, the knowledge of its toxicological effects is essential. In the test of acute toxicity, only the highest dose of $5 \mathrm{~g} / \mathrm{kg}$ of EEAE caused an increase in liver weight, suggesting hepatotoxicity at 
this dose. However, in the group treated with EEAE (2 $\mathrm{g} / \mathrm{kg}$ ), no alterations were observed in the organs or in the haematological, biochemical and toxic parameters assessed. Therefore, based on the guidelines of the Organization for Economic Co-operation and Development, the lethal dose $\left(L_{50}\right)$ of $A$. edulis is higher than $5 \mathrm{~g} / \mathrm{kg}$ and EEAE can be considered an extract of low toxicity.

\section{Conclusion}

The results of the present study show that the extract of leaves of $A$. edulis has antioxidant activity in vitro by scavenging free radicals and inhibiting hemolysis and lipid peroxidation in human erythrocytes incubated with an oxidizing agent. It was active against the bacterium $S$. aureus, as well as showed low toxicity. The antioxidant and antimicrobial activities of this extract can be attributed to the presence of flavonoids and phenolic compounds. Therefore, these results suggest that this natural product may be used for the treatment and/or prevention of various diseases related to microorganisms and oxidative stress.

\section{Conflict of interest}

The authors declare that there are no conflicts of interest.

\section{ACKNOWLEDGEMENTS}

The authors thank the members of GEBBAM for their supports in carrying out the experiments, Dr. Andreia Sangalli for botanically identifying the species. This work was supported by grants of the Fundação de Apoio ao Desenvolvimento do Ensino, Ciência e Tecnologia do Mato Grosso do Sul (FUNDECT), Conselho Nacional de Desenvolvimento Cientıfico e Tecnológico (CNPq) and coordenação de Aperfeiçoamento de Pessoal de Nível Superior (CAPES).

\section{REFERENCES}

Abreu DCA, Nogueira AC, Medeiros AC de S (2005). Caracterização morfológica de frutos, sementes e germinação de Allophylus edulis (St.-Hil) Radlk. (Sapindaceae). Rev. Bras. Sementes 2:59-66.

Alves EOM, Soares TS, Vieira M do Carmo, Silva CB (2008). Levantamento etnobotânico e caracterização de plantas medicinais em fragmentos florestais de Dourados, MS. Ciênc. Agrotec. 32:651658.

Asare GA., Addo P, Bugyei K, Gyan B, Adjei S, Otu-Nyarko LS, Wiredu EK, Nyarko A (2011). Acute toxicity studies of aqueous leaf extract of Phyllanthus niruri. Interdiscip. Toxicol. 4:206-210.
Bakker-Woudenberg IA, van Vianen W, van Soolingen D, Verbrugh HA, van Agtmael MA (2005). Antimycobacterial agents differ with respect to their bacteriostatic versus bactericidal activities in relation to time of exposure, mycobacterial growth phase, and their use in combination. Antimicrob. Agents Chemother. 49(6):2387-2398.

Bandoni ALM, Rondina RVD, Coussio JD (1972). Survey of Argentine medicinal plants. Folklore and phytomedicine screening. Lloydia 35:69-80.

Barbosa WLR, Quignard E, Tavares ICC, Pinto LN, Oliveira FQ, de Oliveira RM (2004). Manual para Análise Fitoquímica e Cromatográfica de Extratos Vegetais. Revis. Cient. UFPA 4.

Braun CAA (2009). Fisiopatologia: Alterações funcionais na saúde humana. Artmed 1:123-147.

Burda S, Oleszek W (2001). Antioxidant and antiradical activities of flavonoids. J. Agric. Food Chem. 49:2774-2779.

Burton GJ, Jauniaux E (2011). Oxidative stress. Best Pract. Res. Clin. Obstet. Gynaecol. 25:287-299.

Bussmann RW, Malca-Garcia G, Glenn A, Sharon D, Chait G, Diaz D, Pourmand K, Jonat B, Somogy S, Guardado G, Aguirre C, Chan R, Meyer K, Kuhlman A, Townesmith A, Effio-Carbajal J, FriasFernandez F, Benito M (2010). Minimum inhibitory concentrations of medicinal plants used in Northern Peru as antibacterial remedies. J. Ethnopharmacol. 132:101-108.

Calixto JB (2005). Twenty-fiveyears of research on medicinalplants in Latin America: A personal view. J. Ethnopharmacol. 100:131-134.

Campos JF, dos Santos UP, Macorini LF, de Melo AM, Balestieri JB, Paredes-Gamero EJ, Cardoso CA, de Picoli Souza K, dos Santos EL (2014). Antimicrobial, antioxidant and cytotoxic activities of propolis from Melipona orbignyi (Hymenoptera, Apidae). Food Chem. Toxicol. 65:374-380.

Casagrande JC, Macorini LF, Antunes KA, Santos UP, Campos JF Dias-Júnior NM, Sangalli A, Lima Cardoso CA, do Carmo Vieira M, Rabelo LA, Paredes-Gamero EJ, Dos Santos EL, de Picoli Souza K (2014). Antioxidant and cytotoxic activity of hydroethanolic extract from Jacaranda decurrens leaves. PLoS One 9(11):e112748.

Cowan MM (1999). Plant Products as Antimicrobial Agents. Clin. Microbiol. Rev. 12:564-582.

Cushnie TP, Lamb AJ (2005). Antimicrobial activity of flavonoids. Int. J. Antimicrob. Agents 26:343-356

Diaz M, Gonzalez A, Castro-Gamboa I, Gonzalez D, Rossini C (2008). First record of L-quebrachitol in Allophylus edulis (Sapindaceae). Carbohydr. Res. 343:2699-2700.

Díaz M, Castillo L, Díaz CE, Álvarez RG, González-Coloma A, Rossini C (2014). Differential deterrent activity of natural products isolated from Allophylus edulis (Sapindaceae). Adv. Biol. Chem. 4:168-179.

Dryden GW, Song M, McClain C (2006). Polyphenols and gastrointestinal diseases. Curr. Opin. Gastroenterol. 22:165-170.

Engels C, Schieber A, Ganzle MG (2011). Inhibitory spectra and modes of antimicrobial action of gallotannins from mango kernels (Mangifera indica L.). Appl. Environ. Microbiol. 77:2215-2223.

Farber JL (1994). Mechanisms of cell injury by activated oxygen. Environ. Health Perspct. 102:17-24.

Félix-Silva J, Giordani RB, da Silva-Jr AA, Zucolotto SM, FernandesPedrosa Mde F (2014). Jatropha gossypiifolia L. (Euphorbiaceae): A Review of traditional uses, phytochemistry, pharmacology, and toxicology of this medicinal plant. Evid. Based Complement. Altern. Med. 2014:369204.

Garg V, Dhar VJ, Sharma A, Dutt R (2012). Facts about standardization of herbal medicine: a review. Zhong Xi Yi Jie He Xue Bao 10:10771083.

Guay DR (2003). Treatment of bacterial skin and skin structure infections. Expert. Opin. Pharmacother. 4:1259-1275.

Gupta D, Gupta RK (2011). Bioprotective properties of Dragon's blood resin: in vitro evaluation of antioxidant activity and antimicrobial activity. BMC Complement. Altern. Med. 11:13-22.

Halliwell B (1992). Reactive oxygen species and the central nervous system. J. Neurochem. 59: 1609-1623. 
Hendra R, Ahmad S, Sukari A, Shukor MY, Oskoueian E (2011). Flavonoid Analyses and Antimicrobial Activity of Various Parts of Phaleria macrocarpa (Scheff.) Boerl. Fruit. Int. J. Mol. Sci. 12:34223431.

Kamicker BJ, Sweeney MT, Kaczmarek F, Dib-Hajj F, Shang W, Crimin K, Duignan J, Gootz TD (2008). Bacterial efflux pump inhibitors. Methods Mol. Med. 142:187-204.

Lee SK, Mbwambo ZH, Chung H, Luyengi L, Gamez EJ, Mehta RG Kinghorn AD, Pezzuto, JM (1998). Evaluation of the antioxidant potential of natural products. Comb. Chem. High. Throughput. Screen 1:35-46.

Liberio SA, Pereira ALA, Dutra RP, Reis AS, Araújo MJAM, Mattar NS, Silva LA, Ribeiro, MN, Nascimento, FR, Guerra, RN, Monteiro-Neto V (2011). Antimicrobial activity against oral pathogens and immunomodulatory effects and toxicity of geopropolis produced by the stingless bee Melipona fasciculata Smith. BMC Complement. Altern. Med. 11:1-10.

McClatchey WC, Mahady GB, Bennett BC, Shiels L, Savo V (2009). Ethnobotany as a pharmacological research tool and recent developments in CNS-active natural products from ethnobotanical sources. Pharmacol. Ther. 123:239-254.

Meda A, Lamien CE, Romito M, Millogo J, Nacoulma OG (2005). Determination of the total phenolic, flavonoid and proline contents in Burkina Fasan honey, as well as their radical scavenging activity. Food Chem. 91:571-577.

Middleton E Jr (1998). Effect of plant flavonoids on immune and inflammatory cell function. Adv. Exp. Med. Biol. 439:175-182.

Mokale KAL, Ngono Ngane RA, Kuiate JR, Koanga Mogtomo ML, Tchinda Tiabou A, Mouokeu RS, Biyiti L, Amvam Zollo PH (2011). Antibacterial and Antioxidant Properties of the Methanolic Extract of the Stem Bark of Pteleopsis hylodendron (Combretaceae). Chemother Res. Pract. 2011:218750.
NCCLS (2005). Performance standards for antimicrobial disk susceptible test: Approved standard M2-A8, 15 ed., CLSI/NCCLS document M100-S15[ISBN 1-56238-556-9 Wayne.

Organisation for Economic Co-operation and Development (OECD) (2008). Guideline 425: Acute Oral Toxicity-Up-and-Down-Procedure 4. Head of Publications Service, Paris p 27.

Raposo RBN, Silva FA, Polonini (2014). Antioxidant plants from Brazil. In Dubey NK. Plants as a natural Antioxidants. Chapter 4:97-109.

Russell AD (2002). Antibiotic and biocide resistance in bacteria: introduction. J. Appl. Microbiol. 92 Suppl:1S-3S.

Silva BM, Santos RP, Mendes LS, de Pinho PG, Valentão P, Andrade PB, Pereira JA, Carvalho M (2011). Dracaena draco L. fruit: Phytochemmical and antioxidant activity assessment. Food. Res. Intern. 44:2182-2189.

Simões CM, Gosman G, Mello JCP, Mentz LA, Petrovick PR (2004). Farmacognosia da planta ao medicamento. Edititora URGS 5:1102. Umeo SH, Ito TM, Yokota ME, Romagnolo MB, Laverde-Junior A (2011). Avaliação das propriedades antioxidantes, anticolinesterásicas e citotóxicas dos frutos de Allophylus edulis (A.St.-Hil., Cambess. \& A. Juss.) Radlk. (Sapindaceae). Arq. Cien. Saúde 15:167-171.

Valente MJ, Baltazar AF, Henrique R, Estevinho L, Carvalho M (2011). Biological activities of Portuguese propolis: Protection against free radical-induced erythrocyte damage and inhibition of human renal cancer cell growth in vitro. Food Chem. Toxicol. 49:86-92.

Yajia ME, Martí DA, Bidau AG, Amat AG, Silvestroni A (1999). Genotoxicity evaluation of Allophylus edulis (Camb.) Radlk. (Sapindaceae) aqueous extract. Acta Hortic. 501:31-35. 